\title{
THE IDENTIFICATION OF VOLATILE AROMA COMPOUNDS FROM LOCAL FRUIT BASED SPIRITS USING A HEADSPACE SOLID-PHASE MICROEXTRACTION TECHNIQUE COUPLED WITH THE GAS CHROMATOGRAPHY-MASS SPECTROMETRY
}

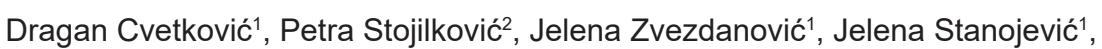
Ljiljana Stanojević ${ }^{1}$, Ivana Karabegović ${ }^{1}$

1 University of Niš, Faculty of Technology, Leskovac, Serbia

$2 \mathrm{PhD}$ student at University of Niš, Faculty of Technology, Leskovac, Serbia

The optimization of the headspace solid-phase microextraction in combination with the gas chromatography-mass spectrometry (HS-SPME-GC/MS) for the qualitative identification of the aroma compounds in fruit spirits (Williams, plum spirit, grape spirit, apricot spirit) was the subject of the presented paper. The SPME extraction conditions (temperature, time, and $\mathrm{NaCl}$ amount) have been varied in order to achieve the more efficient chromatographic separation of the gas mixtures, to efficiently salt-out a higher number of less volatile compounds, and to save the energy during the sample preparation. Optimal parameters were determined as: $T=40^{\circ} \mathrm{C} ; m_{\mathrm{NaCl}}=2$ g; dilution = 10 times. According to the results obtained, the analyzed samples of Serbian fruit spirits produced from different fruits have a comparable composition of volatile aroma compounds to whiskey. The detection and definition of specific compounds that are "fingerprint" of fruit spirits could be an efficient method of the product authentication developing.
(ORIGINAL SCIENTIFIC PAPER)

UDC 663.551.5:543.4+543.544.3

DOI: $10.5937 /$ savteh2002019C

Keywords: fruit spirits, aroma compound, HS-SPME, GC/MS

\section{Introduction}

Headspace solid-phase microextraction (HS-SPME) is a fast, clean and simple extraction technique widely used for volatile (aroma) compounds extraction [1]. In combination with the gas chromatography-mass spectrometry (GC/MS), it provides a fast and sensitive detection of volatile compounds although the extraction itself depends on numerous parameters such as temperature, time, ionic strength, sample matrix etc. Having this in mind, the optimization of the extraction process is required to achieve a high efficiency. Gas chromatography coupled with MS and FID (Flame lonization Detector) detectors was used for the qualitative and quantitative analysis of volatile mixtures from spirit drinks [1-3]. The SPME method has been developed to respond to the need for rapid pre-processing and the preparation of laboratory samples in the lab and in situ [4].

Alcoholic beverages have a long and widespread history in human civilization. Except for the people in the Arctic and those at the southern tip of South America, almost every culture traditionally consumes and produces its alcoholic beverages [5]. Spirit-based beverages are very popular today being produced by ethanol fermentation and distillation of raw fruits with the minimum ethanol content of $37.5 \%$. The most frequently used fruits are plums, apricots, cherries, pears and apples. Plum spirits are convincingly the most popular ones, largely produced by the Czech Republic, Poland, Slovakia, Hungary, Bulgaria, Serbia and Romania [6,7].
A mixture of volatiles compounds that originate from fruits or arise in the spirits production stages give an irreplaceable sensory characteristic (smell and mostly taste i.e. flavor) to fruit spirits. Each flavor component is characteristic for the different stage of the fruit spirit production. The "primary" flavor substances originate from fruits, while "secondary" ones occur during fermentation. "Tertiary" flavor substances are formed during distillation, and "quarterly" during ripening of fruit distillates in wooden vessels (barrels and kegs). Through their mutual interaction, a series of flavor compounds is created that give the irreplaceable senses to the fruit spirits produced. These (semi)volatile compounds including aldehydes, ketones, acids, alcohols, terpenes, esters and other compounds in traces make the unique aroma and taste profile of any fruit spirit $[7,8]$.

The manufacturers of spirits need to ensure the constant quality of the products by constant monitoring of the aroma compounds composition. The wide concentrations range, different polarities, and the number of functional groups in structures of the volatile compounds that make the taste/aroma profiles can make a sample analysis very complicated. Simple techniques that use no solvent, and span a wide range of analytes are desirable [8]. Volatile compounds from spirits include alcohols, aldehydes, ketones, esters, furans, aromatics, compounds containing sulfur, nitrogen, acetals and other components. Different flavors come from these compounds contributing to very

\footnotetext{
*Author address: Dragan Cvetković, Faculty of Technology, Bulevar Oslobođenja 124, 16000 Leskovac, Serbia

E-mail: cvetkovic@tf.ni.ac.rs; dragancvetkovic1977@yahoo.com

The manuscript received: May, 20, 2020.

Paper accepted: Jul, 27, 2020.
} 
complex tastes of spirits [2].

The complex composition of fruit spirits is investigated worldwide in order to control the content of compounds that could negatively affect human health, such as methanol, ethyl carbamates and hydrogen cyanide, as well as to authenticate the products and identify their botanical and geographical characteristics [6]. In this study, the experimental conditions were optimized to develop a fast and sensitive method based on manual static HS-SPME sampling using gas chromatography and mass spectrometry for the qualitative determination of volatile constituents of spirits. The main objective of this work was the extraction of aroma/ taste compounds from different samples (fruit spirits taken from local farms) by the HS-SPME technique and the identification by GC/MS and GC/FID chromatography.

\section{Experimental}

\section{Material}

Different types of fruit spirits from local farms were used to optimize the SPME extraction. Fruit spirits made from different fruits: Williams pear ( $\left.\mathrm{S}_{1}\right)$, plum ( $\mathrm{S}_{2}, \mathrm{I}$ - IV), grape $\left(\mathrm{S}_{3}\right)$ and apricot ( $\mathrm{S}_{4}$ ). A sample of unkown origin ( $\mathrm{S}_{5}$ ), was used for comparison and its origin prediction. The optimization of the SPME method was done with $\mathrm{S}_{1}$ sample.

The ethanol content in all samples was determined pycnometrically.

Extraction of volatile compounds from the spirits by headspace-solid phase microextraction (HS-SPME)

SPME manual holder and fused silica fiber coated with Carboxen ${ }^{\circledast / P o l y d i m e t i l s i l o x a n e ~(C A R / P D M S) ~ s t a t i o n a r y ~}$ phase (75 $\mu \mathrm{m}$ thickness) were purchased from Supelco (Bellefonte, PA, USA) and used for the extraction of aroma compounds from wine samples by HS-SPME. Before the first use, the fiber was preconditioned according to the manufacturer's instruction $\left(1 \mathrm{~h}\right.$ at $\left.300^{\circ} \mathrm{C}\right)$. Ten milliliters of the spirit samples, diluted in the adequate proportion with redistilled water, a certain amount of $\mathrm{NaCl}$ and magnetic stirrer bar were placed in a $20 \mathrm{ml}$ amber glass bottle, closed with a rubber septum and sealed with parafilm. To achieve the equilibration state, the samples were heated at the adequate temperature and agitated with a magnetic stirrer for 15 minutes (pre-extraction). The SPME fiber was then inserted into the headspace of the sample, and the volatiles were extracted for 30 minutes with constant heating and stirring at the given temperature. The fiber was then desorbed for 10 minutes in split/splitless inlet set at $250^{\circ} \mathrm{C}$ in 20:1 split mode and analyzed by GC/MS and GC/FID chromatography.

Gas chromatography-mass spectrometry (GC/MS) analysis and gas chromatography-flame ionization detection (GC/FID) of volatile compounds

GC/MS analysis of the volatiles from the samples was performed on Agilent Technologies 7890B gas chromatograph, coupled with inert, selective 5977A mass detector of the same company. Components were separated on weakly polar, silica capillary column, HP-5MS (5\% diphenyl- and $95 \%$ dimethyl-polysiloxane, $30 \mathrm{~m} \times 0.25 \mathrm{~mm}, 0.25 \mu \mathrm{m}$ film thickness; Agilent Technologies, Santa Clara, CA, USA). Helium was used as the carrier gas, at a constant flow rate of $1 \mathrm{ml} / \mathrm{min}$. The GC oven temperature was held for $2 \mathrm{~min}$ at $40^{\circ} \mathrm{C}$, increased to $250{ }^{\circ} \mathrm{C}$ at the rate of $7^{\circ} \mathrm{C} / \mathrm{min}$, and finally held at $250{ }^{\circ} \mathrm{C}$ for $2 \mathrm{~min}$. The total run time was $34 \mathrm{~min}$. Separated components were further analyzed by a mass spectrometer. Temperatures of the MSD transfer line, ion source and quadrupole mass analyzer were set at $300^{\circ} \mathrm{C}, 230^{\circ} \mathrm{C}$ and $150^{\circ} \mathrm{C}$, respectively. The ionization voltage was $70 \mathrm{eV}$ and the mass detection was done in the Scan mode, in $\mathrm{m} / \mathrm{z}$ range from 25 to 550 .

Data processing was performed using MSD ChemStation (revision F.01.00.1903) in combination with AMDIS (revision 2.70) and NIST MS Search (version 2.0g) softwares (Agilent Technologies, Santa Clara, CA, USA). Retention indices of the components from the samples were experimentally determined using a homologous series of $n$-alkanes from $\mathrm{C}_{8}-\mathrm{C}_{20}$ as standards, analyzed under identical GC/MS and GC/FID conditions. The identification of compounds was based on the comparison of experimentally obtained linear retention indices with those found in the literature (Adams, 2007), as well as on the comparison of their El (Electron lonization) mass spectra with the data from Willey 6, NIST11 and RTLPEST 3 mass spectra libraries.

\section{Results and discussion}

The results of alcohol determination in the samples pycnometrically are shown in Table 1.

Table 1. The alcohol content in the investigated fruit spirits determined pycnometrically

\begin{tabular}{cc}
\hline Sample & Alcohol content, \\
\hline & $\%$ vol \\
$\mathrm{S}_{1}$ & 40.2 \\
$\mathrm{~S}_{2}(\mathrm{I})$ & 53.4 \\
$\mathrm{~S}_{2}(\mathrm{II})$ & 47.1 \\
$\mathrm{~S}_{2}(\mathrm{III})$ & 47.4 \\
$\mathrm{~S}_{2}(\mathrm{IV})$ & 43.3 \\
$\mathrm{~S}_{3}$ & 54.3 \\
$\mathrm{~S}_{4}$ & 40.1 \\
\hline
\end{tabular}

Table 2. The experimental conditions varied during the optimization process using $\mathrm{S}_{1}$ sample

\begin{tabular}{|c|c|c|}
\hline $\begin{array}{c}m_{\mathrm{NaCl}}, \\
\mathrm{g}\end{array}$ & ${ }^{T} \mathrm{C}$ & $\begin{array}{c}\text { Dilution } \\
\left(V_{\text {final }} / V_{\text {spirit }}\right)\end{array}$ \\
\hline \multirow{6}{*}{0} & \multirow{2}{*}{22} & 10 \\
\hline & & 20 \\
\hline & \multirow{2}{*}{40} & 10 \\
\hline & & 20 \\
\hline & \multirow{2}{*}{60} & 10 \\
\hline & & 20 \\
\hline \multirow{6}{*}{1} & \multirow{2}{*}{22} & 10 \\
\hline & & 20 \\
\hline & \multirow{2}{*}{40} & 10 \\
\hline & & 20 \\
\hline & \multirow{2}{*}{60} & 10 \\
\hline & & 20 \\
\hline \multirow{6}{*}{2} & \multirow{2}{*}{22} & 10 \\
\hline & & 20 \\
\hline & \multirow{2}{*}{40} & 10 \\
\hline & & 20 \\
\hline & \multirow{2}{*}{60} & 10 \\
\hline & & 20 \\
\hline
\end{tabular}


The HS-SPME extraction conditions were optimized in terms of more efficient chromatographic separation and present compounds identification. The $\mathrm{S}_{1}$ sample was analyzed under conditions that were varied by the scheme given in Table 2. Pre-extraction of the samples for $15 \mathrm{~min}$ followed by the extraction for $30 \mathrm{~min}$, at the selected temperature was performed in all further experiments.

Table 3. The aroma compounds identified by HS-SPME/GC-MS techniques from $\mathrm{S}_{1}$ sample under different SPME conditions (pre-extraction temperature, $\mathrm{NaCl}$ quantity and dilution degree)

\begin{tabular}{|c|c|c|c|c|c|}
\hline No. & Compound & $\begin{array}{c}T=60^{\circ} \mathrm{C} ; \\
m_{\mathrm{NaCl}}=0 ; \\
\text { dil. }=10 \text { times }\end{array}$ & $\begin{array}{c}T=40{ }^{\circ} \mathrm{C} \\
m_{\mathrm{NaCl}}=1 \mathrm{~g} ; \\
\text { dil. }=10 \text { times }\end{array}$ & $\begin{array}{c}T=40{ }^{\circ} \mathrm{C} \\
m_{\mathrm{NaCl}}=2 \mathrm{~g} ; \\
\text { dil. }=10 \text { times }\end{array}$ & $\begin{array}{c}\text { Aroma } \\
\text { description }\end{array}$ \\
\hline 1. & Methanol & + & + & + & \\
\hline 2. & Ethanol & + & + & + & Sweet \\
\hline 3. & 1-Propanol & + & + & + & Alcohol, strong \\
\hline 4. & 2-Methyl-1-propanol & + & - & + & Alcohol \\
\hline 5. & 2-Butanol & + & - & - & \\
\hline 6. & Ethyl acetate & + & + & + & Fruity, sweet \\
\hline 7. & 3-Methyl-1-butanol & + & + & + & $\begin{array}{l}\text { Whiskey, malt, } \\
\text { scorched }\end{array}$ \\
\hline 8. & 2-Methyl-1-butanol & + & + & + & Malt \\
\hline 9. & Furfural & - & + & - & \\
\hline 10. & Isoamyl acetate & - & + & + & $\begin{array}{l}\text { Banana, fruit, } \\
\text { pear }\end{array}$ \\
\hline 11. & 1-Hexanol & + & + & + & Grass, resin \\
\hline 12. & Ethyl hexanoate & - & - & + & Fruity, anise \\
\hline 13. & Hexyl acetate & + & + & + & Fruity. herbal \\
\hline 15. & 1-Ethynyl-4-methoxybenzene & + & + & + & \\
\hline 16. & 3-Acetoxy dodecane & - & - & + & \\
\hline 17. & $\begin{array}{l}\text { Ethyl hexanoate } \\
\text { 1-Methylene-2b-hydroxymethyl-3,3- }\end{array}$ & - & + & - & Fruity, anise \\
\hline 18. & $\begin{array}{l}\text { dimethyl-4b-(3-methylbut-2-enyl)- } \\
\text { cyclohexane }\end{array}$ & - & + & - & \\
\hline 19. & Ethyl benzoate & + & + & + & \\
\hline 20. & Ethyl octanoate & + & + & + & $\begin{array}{l}\text { Pineapple, pear, } \\
\text { floral }\end{array}$ \\
\hline 21. & Estragole & - & + & + & Anise \\
\hline 22. & 2-Phenylethyl acetate & - & - & + & Pleasant, floral \\
\hline 23. & $n$ - Decanoic acid & + & + & + & Oily, unpleasant \\
\hline 24. & Methyl decanoate & - & - & + & Wine \\
\hline 25. & $\begin{array}{l}\text { 1-(2,6,6-trimethyl-1,3-cyclohexadien-1-yl)- } \\
\text { 2-buten-1-one }\end{array}$ & - & + & + & \\
\hline 26. & Ethyl decanoate & + & + & + & $\begin{array}{l}\text { Fruity, oily, } \\
\text { pleasant }\end{array}$ \\
\hline 28. & ethyl trans-2-decenoate & + & + & + & \\
\hline 29. & Decanedioic acid 2,4 diethyl ester & + & + & + & Pear \\
\hline 30. & 2-Phenoxyethyl isobutyrate & - & - & + & \\
\hline 31. & $\begin{array}{l}\text { Cyclopropane, (R,R)-1-((Z),(Z)-hexa-1',3'- } \\
\text { dienyl)-2-etenil }\end{array}$ & - & + & - & \\
\hline 32. & Dodecanoic acid & + & - & - & \\
\hline 33. & Ethyl dodecanoate & + & + & + & Floral, fruity \\
\hline
\end{tabular}

The compounds identified by HS-SPME-GC/MS and HS-SPME-GC/FID methods under different (selected) SPME experimental conditions are given in Table 3, while the selected TIC (Total Ion Chromatogram) chromatograms of the $\mathrm{S}_{1}$ sample, analyzed under different experimental conditions, are shown in Figure 1.

${ }^{1}$ According to: http://www.flavornet.org/flavornet.html; [22-25] 


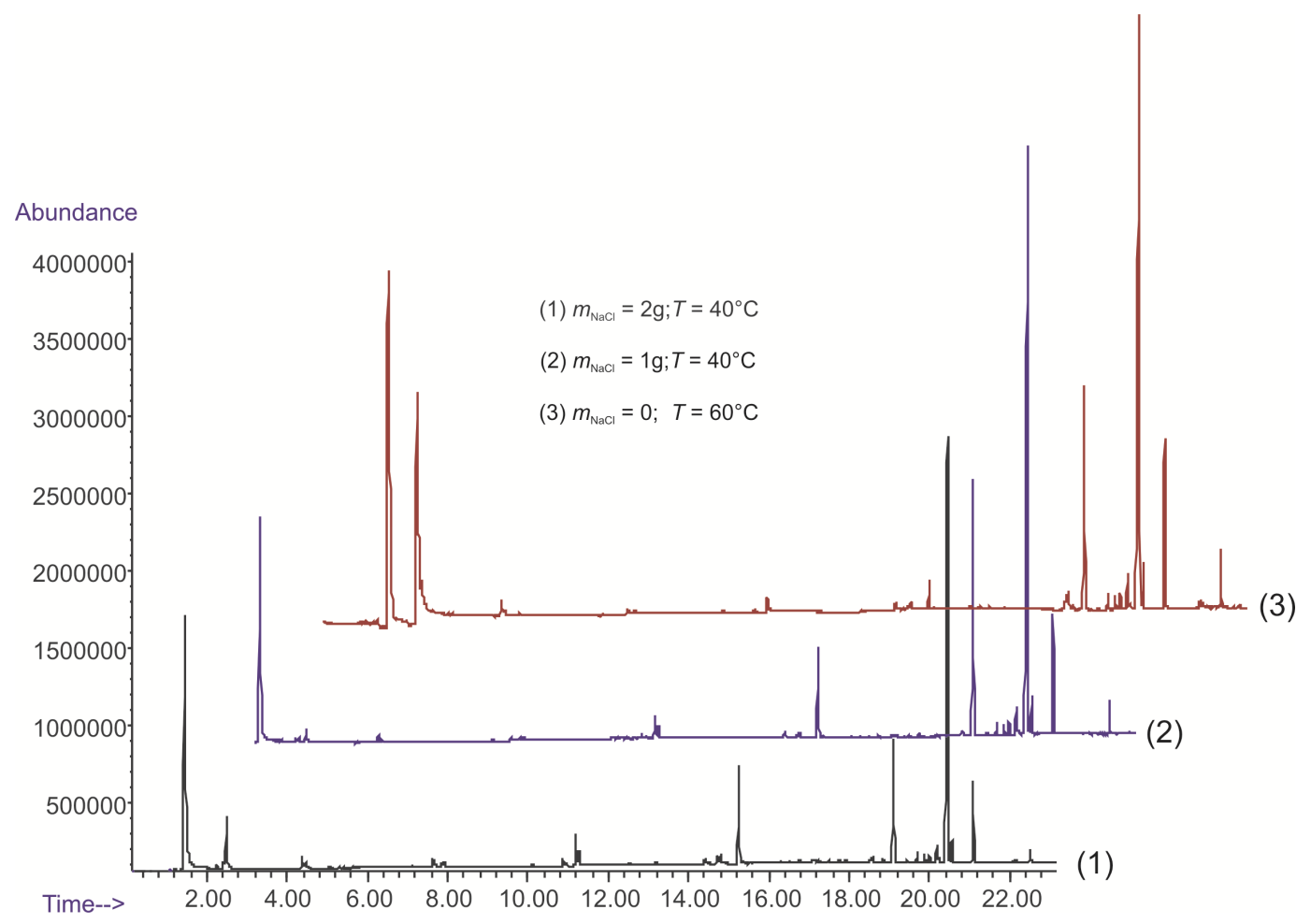

Figure 1. TIC chromatograms of $\mathrm{S}_{1}$ sample measured under different experimental conditions indicated in the Figure. The sample was diluted 10 times for each measurement

Numerous factors affect the analytes sorption from the gas phase, so the optimization of HS-SPME method was aimed at the increase in the method efficiency, a decrease of the sample amount, and the easier identification of volatile compounds. There are results of the volatile compounds identification from some spirits in the literature, but the authors were mostly oriented to the beverages characteristic for the specific area [2,9$15]$ and the accent was mostly on aroma-compounds from wine samples. The authors have used PDMS fibers $[2,13,15]$ and the fibers of different composition, sorbent thickness and modified polarity - CAR/PDMS [10] and DVB/CAR/PDMS $[9,11,12]$. The SPME extraction conditions (temperature, time, and $\mathrm{NaCl}$ amount) have been mainly varied to efficiently salting-out a higher number of less volatile compounds. Fruit spirits are usually diluted five [15] or ten [2] times.

Bearing in mind the results already published, the CAR/PDMS (Supelco) fiber was chosen for the aromavolatile compounds investigation. The $\mathrm{S}_{1}$ sample with $40.2 \%$ of alcohol has been selected since the Williams pear and its spirits drinks are very popular in Serbia by virtue of specific taste and aroma. It should be emphasized that the differences in chromatograms, under varied conditions listed in Table 2, were mostly reflected in some peaks intensities, especially those at lower retention times. Some representative chromatograms are given in Figure 1, and the identified compounds are listed in Table 3. The remaining chromatograms of $S_{1}$ sample were similar (not shown). According to the number of the identified compounds listed in Table 3 and the chromatograms shown in Figure 1, as well as the certainty level during the identification of the compounds (especially for the compounds with a low concentration at shorter retention times), the conditions selected as optimal were: $T=$ $40^{\circ} \mathrm{C} ; m_{\mathrm{NaCl}}=2 \mathrm{~g}$; dilution $=10$ times. The energy saving during the sample preparation was one of the decision criteria, too.

Other samples were measured under selected optimal conditions. The identified compounds are listed in Table 4, while the chromatograms are shown in Figure 2 ( $\mathrm{S}_{2}$ samples) and Figure $3\left(\mathrm{~S}_{3}, \mathrm{~S}_{4}\right.$ and $\left.\mathrm{S}_{5}\right)$. 
Table 4. The aroma compounds identified by HS-SPME/GC-MS techniques from the samples investigated under optimal SPME conditions: $T=40^{\circ} \mathrm{C} ; m_{\mathrm{NaCl}}=2 \mathrm{~g}$; dilution $=10$ times.

\begin{tabular}{|c|c|c|c|c|c|c|c|c|c|}
\hline No. & Compound & ฟิ & હิ & ્ָస & $\underset{\text { ฟ }}{\stackrel{\Sigma}{\Sigma}}$ & ๗̧ & ङ & ฒ & Aroma description ${ }^{1}$ \\
\hline 1. & Methanol & + & + & + & + & - & + & + & \\
\hline 2. & Acetaldehyde & - & - & - & - & + & - & - & \\
\hline 3. & Ethanol & + & + & + & + & + & + & + & Sweet \\
\hline 4. & Methyl acetate & - & - & - & + & + & + & - & \\
\hline 5. & 1-Propanol & + & + & + & + & + & + & - & Alcohol, strong \\
\hline 6. & Styrene & + & + & + & + & - & + & - & Balsamic, petrol \\
\hline 7. & Benzaldehyde & + & + & + & + & - & + & + & Almond \\
\hline 8. & Ethyl acetate & + & + & + & + & + & + & + & Fruity, sweet \\
\hline 9. & O-Allylhydroxylamine & - & - & + & - & - & - & - & \\
\hline 10. & 2-Methyl-1-propanol & - & + & - & + & + & + & + & Alcohol \\
\hline 11. & 24 5-Trimethyl-1 3-dioxolane & - & - & - & - & + & - & - & \\
\hline 12. & 1,1-Diethoxyethane & - & - & - & - & + & - & + & \\
\hline 13. & 3-Methyl-1-butanol & + & + & + & + & + & + & + & $\begin{array}{l}\text { Whiskey, malt, } \\
\text { scorched }\end{array}$ \\
\hline 14. & 2-Methyl-1-butanol & + & + & + & + & + & + & - & Malt \\
\hline 15. & 2-Methyl butyl acetate & - & - & - & - & + & - & - & \\
\hline 16. & Ethyl 2-methyl butanoate & - & - & - & - & - & + & - & \\
\hline 17. & 2,6-Dimethyl-2,7-octadiene-1,6-diol & - & - & - & - & + & - & - & \\
\hline 18. & Furfural & - & + & + & + & - & - & + & Bread, almond, sweet \\
\hline 19. & $\beta$-Pinene & - & - & - & + & - & - & - & \\
\hline 20. & a-Pinene & - & - & - & - & - & + & - & Pine, turpentine \\
\hline 21. & 2-Nonenal (E) & - & - & - & - & + & - & - & \\
\hline 22. & 2-Butenoic acid ethyl ester & - & + & & - & - & - & + & \\
\hline 23. & Diethyl succinate & - & - & - & - & + & - & - & \\
\hline 24. & Benzeneacetic acid, ethyl ester & - & - & - & - & + & - & - & \\
\hline 25. & Methyl benzoate & + & - & - & - & - & - & - & Dry plum, lettuce \\
\hline 26. & 3 7-Dimethyl-1 6-octadien-3-ol & + & - & - & - & - & + & - & Banana, fruit, pear \\
\hline 27. & 1-Hexanol & - & - & + & + & + & + & + & Herbaceous, resinous \\
\hline 28. & Isoamyl acetate & - & - & - & - & + & + & + & Banana \\
\hline 29. & Nonanal & + & + & - & + & + & + & - & Oily, citrusy, green \\
\hline 30. & D-Limonene & - & - & + & + & - & + & - & Lemon, orange \\
\hline 31. & 1-Octanol & + & + & + & + & - & + & + & $\begin{array}{l}\text { Moss, walnut, } \\
\text { mushroom }\end{array}$ \\
\hline 32. & 1-Ethenyl-4-metoksi benzene & + & + & + & - & - & - & - & \\
\hline 33. & Phenyl methyl acetate & + & + & + & - & - & - & - & \\
\hline 34. & 1 6-Octadien-3-ol 3,7-dimethyl- 2-aminobenzoate & - & - & + & + & - & - & - & \\
\hline 35. & 1-Nonanol & + & + & + & + & + & + & + & Greasy, green \\
\hline 36. & Ethyl hexanoate & + & + & + & + & + & + & + & Fruity, anise \\
\hline 37. & Octanal & - & - & - & - & - & - & + & Oily, soap, lemon \\
\hline 38. & Hexyl acetate & - & + & - & - & - & - & - & Fruity, herbal \\
\hline 39. & 1,2-diphenyl-1,2-ethanediol & - & + & - & - & - & - & - & \\
\hline 40. & Methyl salicylate & + & - & - & - & - & - & - & Peppermint \\
\hline 41. & 1-Decanol & + & - & - & - & - & + & + & Oily \\
\hline 42. & 2-Hydroxy ethyl benzoate & + & + & + & - & - & - & - & Oily \\
\hline 43. & 1,4-Benzenediamine $\mathrm{N}, \mathrm{N}$-bis(1-metil etil) & + & - & - & - & - & - & - & \\
\hline 44. & Ethyl nonanoate & + & - & + & - & - & + & - & \\
\hline 45. & Terpinen-4-ol & - & - & + & - & - & - & - & $\begin{array}{l}\text { Turpentine, nutmeg, } \\
\text { sea }\end{array}$ \\
\hline 46. & Benzenepropanoic acid, ethyl ester & + & - & - & - & - & - & - & \\
\hline 47. & 2-Phenylethyl acetate & - & - & + & - & + & - & - & Pleasant, floral \\
\hline 48. & Anethole & - & - & + & - & - & - & - & \\
\hline 49. & Ethyl benzoate & + & + & + & + & - & + & + & \\
\hline 50. & Ethyl 2 hydroxybenzoate & - & - & - & + & - & - & - & \\
\hline 51. & Ethyl heptanoate & - & + & + & - & - & - & - & \\
\hline 52. & 3,3-Dimethylcyclohexylidene acetaldehyde & - & - & - & - & - & - & + & \\
\hline 53. & (1,4-Dimethylpent-2-enyl)benzene & - & - & - & - & - & - & + & \\
\hline 54. & Octyl acetate & - & - & - & - & - & - & + & Fruity \\
\hline 55. & 1,5-Dimethyl-1-vinyl-4-hexenyl butyrate & - & - & - & - & - & + & - & \\
\hline 56. & 4-Methyl-1-(1-methylethyl)-3-cyclohexen-1-ol & - & - & - & - & - & + & - & \\
\hline 57. & $\begin{array}{l}2(1 \mathrm{H})-N a p h t h a l e n o n e, 3,4,4 \mathrm{a}, 5,6,7 \text {-hexahydro-1,1,4a- } \\
\text { trimethyl }\end{array}$ & - & - & - & - & - & - & + & \\
\hline 58. & 1-Oxaspiro(4.5)dec-6-ene, 2,6,10,10-tetramethyl & - & - & - & - & - & - & + & \\
\hline 59. & Naphthalene, 1,2,3,4-tetrahydro-1,1,6-trimethyl- & - & - & - & - & - & - & + & \\
\hline 60. & 1,1,5-Trimethyl-1,2-dihydronaphthalene & - & - & - & - & - & - & + & \\
\hline 61. & Heptanoic acid & - & - & - & - & - & - & + & \\
\hline
\end{tabular}




\begin{tabular}{|c|c|c|c|c|c|c|c|c|c|}
\hline 62. & 4-Butyl-indan-5-ol & - & - & - & - & - & - & + & \\
\hline 63. & Benzene, 2-(1,3-butadienyl)-1,3,5-trimethyl & - & - & - & - & - & - & + & \\
\hline 64. & 1,2-Dimethyl-1,5-cyclooctadiene & - & - & - & - & - & - & + & \\
\hline 65. & Ethyl trans-4-decenoate & - & - & - & - & - & - & + & \\
\hline 66. & (E)-1-(2,3,6-Trimethylphenyl)buta-1,3-diene & - & - & - & - & - & - & + & \\
\hline 67. & Edulan II & - & - & - & - & - & - & + & \\
\hline 68. & 2H-1-Benzopyran, 3,5,6,8a-tetrahydro-2,5,5,8a-tetramethyl-, trans- & - & - & - & - & - & - & + & \\
\hline 69. & Nicotinic acid hydrazide & - & + & - & - & - & - & - & \\
\hline 70. & Methyl octanoate & - & + & - & - & - & + & - & Orange \\
\hline 71. & Methyl salicylate & - & + & + & + & - & - & - & Peppermint \\
\hline 72. & Decanal & - & + & - & - & - & - & - & Soap, orange peel \\
\hline 73. & 3,7-Dimethyl-6-octen-1-ol & - & + & - & - & - & + & - & \\
\hline 74. & 3,7-Dimethyl-2,6-octadien-1-ol & - & - & - & - & - & + & - & \\
\hline 75. & L- $\alpha$-Terpineol & - & - & - & - & - & + & - & \\
\hline 76. & 1,7,7-Trimethylbiciklo $(2,2,1)$ hept-2-en & - & + & - & - & - & - & - & \\
\hline 77. & $\beta$-Mircene & - & + & + & - & - & + & - & Balsamic, spicy \\
\hline 78. & 1-Ethynyl-4-methoxybenzene & - & + & - & - & - & - & - & \\
\hline 79. & Ethyl octanoate & + & + & + & + & + & + & + & Pineapple, pear, floral \\
\hline 80. & 3-Methylbutyl octanoate & - & - & - & - & - & - & + & \\
\hline 81. & Ethyl nonanoate & - & + & - & + & - & - & - & \\
\hline 82. & Methyl decanoate & - & + & - & - & - & + & - & Wine \\
\hline 83. & Benzenepropanoic acid, ethyl ester & - & + & + & - & - & - & - & \\
\hline 84. & Eugenol & - & + & + & + & - & - & - & \\
\hline 85. & $n$ - Decanoic acid & + & + & + & + & + & + & - & Oily, unpleasant \\
\hline 86. & 4-Decenoic acid, ethyl ester & - & + & - & - & - & - & - & \\
\hline 87. & 9-Decenoic acid, ethyl ester & + & + & - & - & - & + & - & \\
\hline 88. & 4-Decanoic acid, ethyl ester & - & - & + & - & - & - & - & \\
\hline 89. & 2,4-Decadienoic acid, ethyl ester & + & + & + & - & - & + & - & Wine \\
\hline 90. & 2-Propenoic acid, 3-phenyl ester & - & + & + & + & - & - & - & \\
\hline 91. & 1-(2,6,6-Trimethyl-1,3-cyclohexadien-1-yl)-2-buten-1-one & + & + & + & - & - & - & - & \\
\hline 92. & Ethyl decanoate & + & + & + & + & + & + & + & Fruity, oily, pleasant \\
\hline 93. & 4-(2,6,6-Trimethyl-2-cyclohexen-1-enyl)-butan-2-ol & - & - & - & - & - & + & - & \\
\hline 94. & Ethyl tetradecanoate & + & - & + & - & + & - & - & \\
\hline 95. & Ethyl dodecanoate & + & + & + & + & + & + & + & \\
\hline 96. & Ethyl hexadecanoate & - & - & - & - & + & - & - & \\
\hline 97. & Oxalic acid, dicyclobutyl ester & + & - & + & - & - & - & - & \\
\hline 98. & Oxalic acid, butyl propyl ester & - & - & + & - & - & - & - & \\
\hline
\end{tabular}

${ }^{1}$ The same as previous (Table 3 )
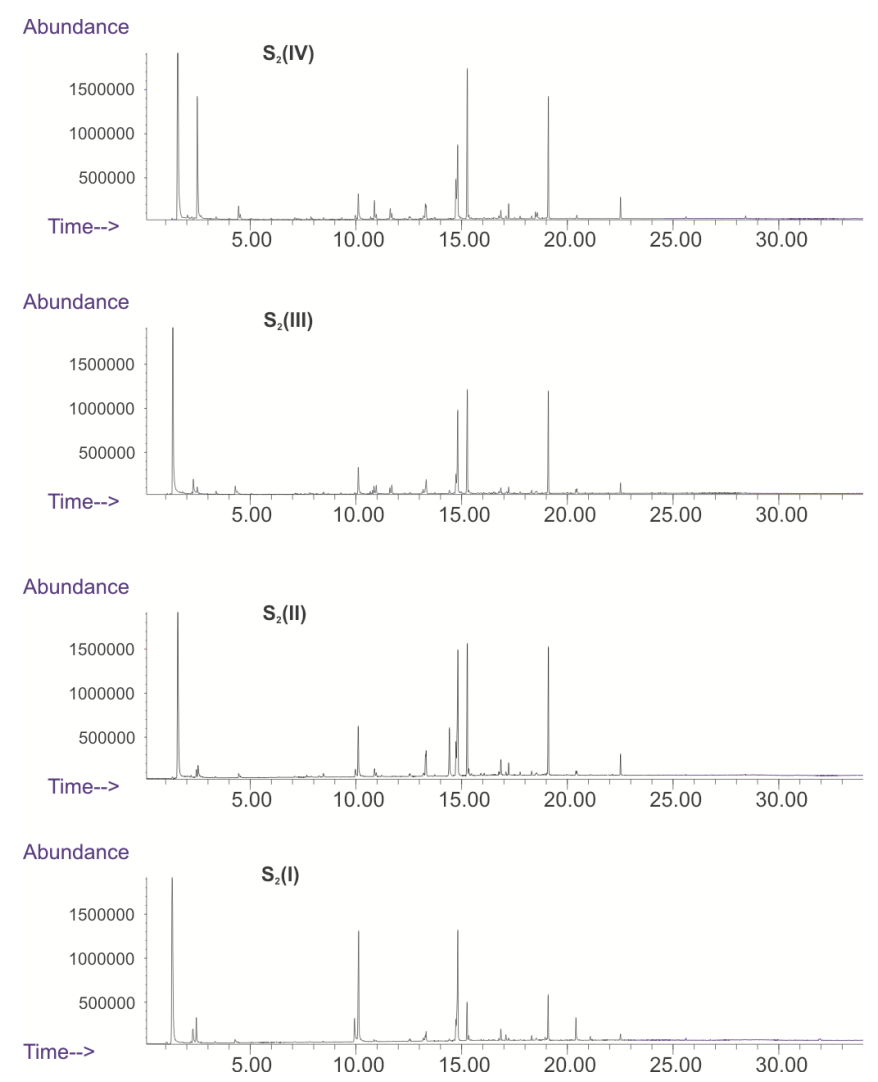

Figure 2. TIC chromatograms of $\mathrm{S}_{2}$ samples (I - IV) measured under optimal experimental conditions: $T=40{ }^{\circ} \mathrm{C}$; $m_{\mathrm{NaCl}}=2 \mathrm{~g}$; dilution $=10$ times. The samples were collected at different local families homesteads 


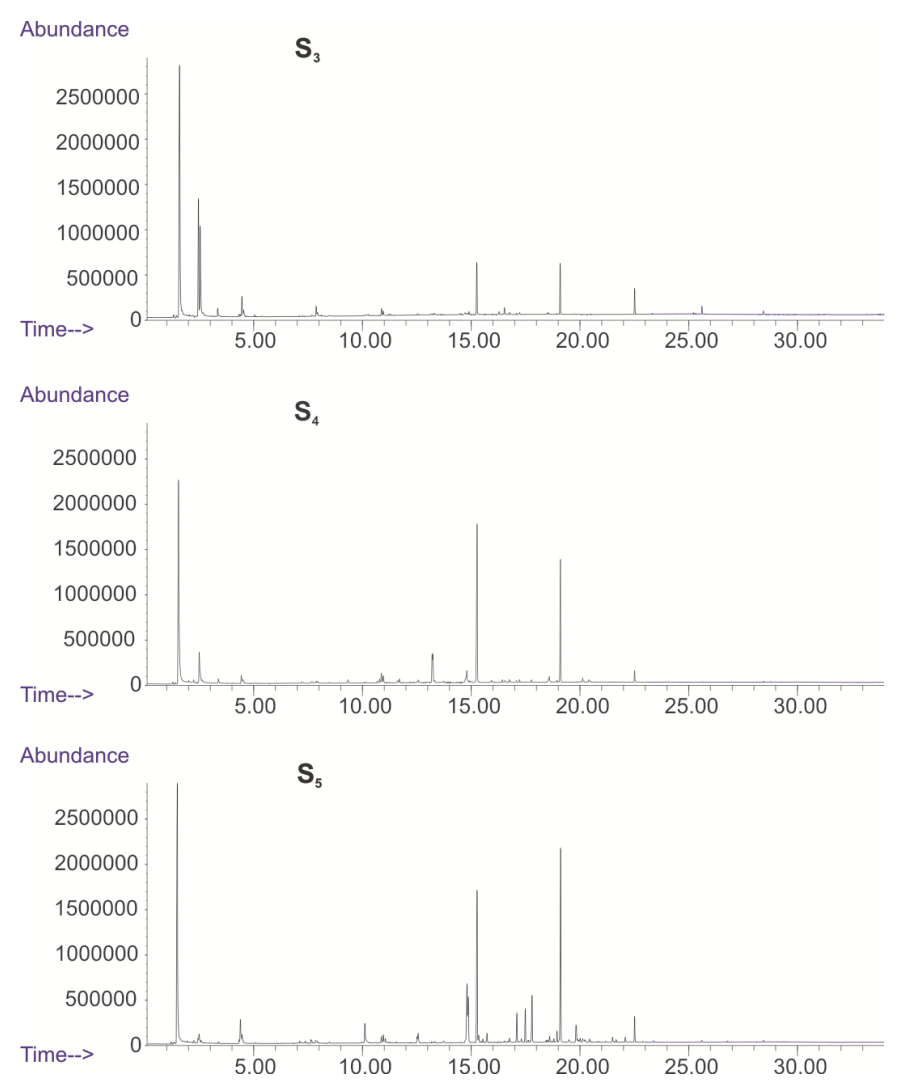

Figure 3. TIC chromatograms of $\mathrm{S}_{3}, \mathrm{~S}_{4}$ and $\mathrm{S}_{5}$ samples measured under optimal experimental conditions: $T=40{ }^{\circ} \mathrm{C}$; $m_{\mathrm{NaCl}}=2 \mathrm{~g}$; dilution $=10$ times. The samples were collected at different local families homesteads

According to the results presented in Tables 3 and 4 , it can be noticed that alcohols are the most represented group of volatile molecules. As expected, ethanol was dominant, eluted at the beginning of each chromatogram (Figs. 1-3). The ethanol concentration could reach $40-70 \%(v / v)$ in spirit drinks. In addition to ethanol, high alcohols such as 2-pentanol, 1-heptanol, 1-octanol, etc. are important ingredients for the spirit aroma. Sweet, fruity and honey aromas, spicy and bakery taste, mostly come from high alcohols [2]. It should be also noticed that methanol was present in the samples (except $S_{3}$ ), eluted immediately before ethanol in a very small quantity, confirming the natural origin of the samples [16]. It is formed by the enzymatic hydrolysis of fruit pectin during the production process. Its increase is, among other things, influenced by the content and the level of methylation of pectins and the activity of pectin methylesterase in the fruit [6]. The most represented higher alcohol in all samples was 3-methyl-1-butanol or isoamyl alcohol. Higher alcohols also include hexanol, octanol, nonanol, and decanol in some samples. The presence of these compounds can cause floral and sweet notes that are considered as a positive characteristic of fruit spirits [2].

Esters represent the compounds that have a major contribution to the spirit aroma formed from secondary metabolics of microorganisms or in a chemical reactions between alcohols and acids. They provide floral, fruity, apple, banana and pineapple flavors, with low sensitivity thresholds. Ethyl hexanoate, ethyl acetate and ethyl lac- tate are the main compounds of the fruit spirits aroma [2]. The esters are absolutely dominant group in the distribution of the overall compounds, and probably the most responsible for the aroma profile of the investigated spirits. It can be concluded that ethyl esters of C8, C10 and C12 acids positively affect the quality of fruit spirits forming fruity and floral sensory properties. Ethyl acetate, with fruity and sweet aroma, was identified in all samples. Isoamyl acetate (isopentyl acetate) with a characteristic banana odor (the main ingredient of "banana oil") was not found in $\mathrm{S}_{2}$ (I), $\mathrm{S}_{2}$ (II) and $\mathrm{S}_{2}$ (IV) samples (Table 4). The presence of 2-phenylethyl acetate, which gives a rose, flower and honey aroma hues, was detected in $\mathrm{S}_{1}$ (Table 3) and S2(III) (Table 4). Hexyl acetate also affects the "fruity" aroma of the samples, while octyl acetate, with a pronounced fruity aroma (often an ingredient of artificial flavoring), was detected only in the $\mathrm{S}_{5}$ (Table 4).

On the other side, aromatic compounds (for example eugenol) have a different aroma depending on their concentration. Eugenol is present in $\mathrm{S}_{2}$ (II), $\mathrm{S}_{2}$ (III) and $\mathrm{S}_{2}$ (IV) samples. It has a fruity aroma at lower and a pungent aroma at higher concentrations [6].

The results obtained by HS-SPME/GC-MS analysis of commercial whiskey samples [17-19] suggest that ethyl esters represent the largest group of volatile compounds in whiskey samples, too. Ethyl esters of $\mathrm{C} 8, \mathrm{C} 10$, and C12 fatty acid (ethyl octanoate above all) and isoamyl alcohol, which contribute to sweet, fruity, and fresh notes, are the main compounds in any of the investigated whis- 
key samples. Isoamyl acetate is one of the most important compounds that contribute to the aroma of whiskey. Comparing the aroma profile of whiskeys with fruit spirits analyzed in this work, concerning mainly the ethyl esters, it can be concluded that ethyl octanoate is the most represented compound in the analyzed samples, whereas isoamyl acetate is not detected only in the plum spirits. Ethyl hexanoate with the green apple and anise aroma identified as an important aromatic active compound in certain whiskey samples [17], was also detected in all samples analyzed. Ethyl benzoate (floral, fruity), ethyl decanoate (fruity), and ethyl dodecanoate (floral, fruity) can be distinguished as ethyl esters that mostly contribute to the aroma of local spirits. Ethyl benzoate was the most dominant in the $\mathrm{S}_{2}$ samples, while it was not identified in the $S_{3}$ (Table 4). It should be noted that ethyl hexadecanoate was identified only in the $S_{3}$, suggesting that this compound, together with ethyl tetradecanoate, gives a decisive influence on the aroma/taste of this grape originated spirit drink.

The higher alcohols found in the whiskey samples were mainly $n-(\mathrm{C} 6)$ and aromatic alcohols. 3-methylbutan-1-ol (fruit), 2-methylpropan-1-ol (bitter, pungent), and 2-phenylethanol are the most common higher alcohols in whiskey [18]. In the samples of homemade Serbian fruit spirits analyzed in this work, in addition to 3-methylbutan-1-ol and 2-methylpropan-1-ol, 1-hexanol (herbaceous, resinous), 1-octanol (moss, walnut, fungus) and 1-nonanol (oily, green) in $\mathrm{S}_{2}$ (IV), $\mathrm{S}_{2}$ (III), $\mathrm{S}_{4}$ and $\mathrm{S}_{5}$ contribute to the aroma. Hexanol and octanol contribute to the aroma of $S_{1}$, hexanol and nonanol to the aroma of $\mathrm{S}_{3}$ Lozovača, while octanol and nonanol to the aroma of $\mathrm{S}_{2}(\mathrm{I})$ and $\mathrm{S}_{2}(\mathrm{II})$. 1-Decanol was found in $\mathrm{S}_{2}(\mathrm{I}), \mathrm{S}_{4}$ and $\mathrm{S}_{5}$ (Table 4).

Degradation of unsaturated fatty or amino acids produces aldehydes and ketones during the fruit spirits production. These compounds usually give fruity, nuts, and floral aromas. Their concentrations are lower than esters or alcohol, but they are easily sensed by the smell sense [2]. On the other side, organic acids give an undesirable taste of rancid cheese, but the right amount of the acids in the spirits can enrich the aroma, and balances it with other compounds. The acids are essential molecules for the ester synthesis [2]. Short-chain organic acids such as acetic, propanoic, butanoic, and lactic acid are byproducts of fermentation. Relatively few organic acids are volatile enough to affect the odor of alcoholic drinks. Acetic acid has the acetic, propanoic acid the goaty, and butanoic acid the rotten butter fragrance. Organic acids are mainly formed during the fermentation process at an earlier stage than corresponding ethyl esters [8].

The C8, C10 and C12 fatty acids, and an extremely small number of aldehydes, were detected in whiskey samples [18]. A similar profile of the mentioned compounds was detected in the samples of Serbian fruit spirits. Hexanoic, octanoic and decanoic acids have a very high aroma index, indicating that these compounds most likely individually contribute to the investigated whiskey aroma [17]. Decanoic acid was identified in our samples, except in the S5 sample (Table 4) where the heptanoic acid was identified. At the same time, the aldehydes were present in a relatively small quantity (Table 4 , Figures 2 and 3), probably due to their reduction to the corresponding alcohols. Nonanal, with citrus and green notes, was not present in $\mathrm{S}_{1}$ (Table 3), $\mathrm{S}_{2}$ (III) and $\mathrm{S}_{5}$, in which the octanal was identified, while $S_{2}$ (II) contained nonanal and decanal (Table 4).

According to Versini et al. (2009), the presence of ethyl octanoate, hexyl 2-methylbutyrate, 1-hexanol, furfural and benzaldehyde enable the distinguishment between the apple varieties [20]. Having in mind that the aroma profile of the $\mathrm{S} 5$ is quite different in comparison to the others, it could be produced from the apples. However, for authenticity confirmation. some additional analytical methods should be used. First of all, UV-Vis spectroscopy and HPLC chromatography for phenolic and phenylpropanoid compounds analysis. Their high concentrations are characteristic for plum spirits and protocatecuic acid for apple spirits. On the other side, quercetin is present only in pear spirits and kaempherol in plum spirits [21], which should be the subject of further studies.

Based on the presented results, it can be concluded that the analyzed samples of Serbian fruit spirits from different fruits have a comparable composition of volatile aroma compounds to whiskey. Although raw materials from which these two types of spirits were produced are completely different, it seems that during fermentation quite a large number of the same or similar volatile compounds that define the aroma profile were formed. Finally, considering the number of compounds identified by the optimized SPME method, a described technique has a great potential in specific aroma compounds identification and the origin of the spirit drinks determination.

\section{Conclusion}

The number of identified compounds, together with a comprehensive consideration of the pre-extraction and chromatographic separation efficiency, were the main optimization criteria. Ethyl esters were present in the highest percentage. These compounds mostly contribute to the aroma of the Serbian fruit spirits defining their specific profile as a function of the raw material (fruit) used. Furthermore, acetates, higher alcohols, fatty acids, aldehydes, and terpenes make a great contribution to the aroma. The type of the identified compounds that define the aroma profile of the investigated Serbian fruit spirits, as well as their relative ratio in the mixture, was comparable to the aroma profile of different whiskey types although many of the identified compounds were not detected in whiskey. At the same time, the differences in the composition of the volatile compounds should be the initial spark for the "fingerprints" of the fruit spirits definition, as well as the fast and efficient authentication method development. 


\section{Acknowledgments}

This work was supported by the Ministry of Education, Science and Technological Development of the Republic of Serbia under the Program of financing scientific research work, number 451-03-68/2020-14/200133.

\section{References}

[1] O.G., Jiang, Solid Phase Microextraction. Recent Developments and Applications, Springer-Verlag $\mathrm{GmbH}$ Germany, 2017.

[2] Q. Liu, Analysis of volatile compounds and their changes during liquor aging of chinese liquor gujing gongjiu, Thesis, Clemson University, 2014.

[3] G. Vas, K. Vekey, Solid-phase microextraction: a powerful sample preparation tool prior to mass spectrometric analysis, Journal of Mass Spectrometry, 39 (2004) 233 254.

[4] J. Pawliszyn, Theory of Solid-Phase Microextraction, Journal of Chromatographic Science, 38(7) (2000) 270 278.

[5] P.E. McGovern, Alcoholic Beverages: Whence and Whither? in Uncorking the past: the quest for wine, beer, and other, alcoholic beverages, University of California Press, Ltd. London, England, 2009, p. 266.

[6] M. Śliwińska, P. Wiśniewska, T. Dymerski, W. Wardencki, J. Namieśnik, The flavour of fruit spirits and fruit liqueurs: a review, Flavour and Fragrance Journal, 30 (2015) 197 $-207$.

[7] Consumption of alcoholic beverages, in IARC Monographs on the Evaluation of Carcinogenic Risks to Humans, Volume 96, Alcohol Consumption and Ethyl Carbamate, Lyon, France, 2010, p.41.

[8] J. Stuff, J. Whitecavage, J. Grandy, J. Pawliszyn, Analysis of beverage samples using Thin Film Solid Phase Microextraction (TF-SPME) and Thermal Desorption GC/ MS, GERSTEL Application Note No. 200 (2018) 1 - 9.

[9] D.C. Ferreira, K. Cardoso Hernandes, K. Primieri Nicolli, E. A. Souza-Silva, V. Manfroi, C. Alcaraz Zini, J. Welke, Development of a Method for Determination of Target Toxic Carbonyl Compounds in Must and Wine Using HSSPME-GC/MS-SIM After Preliminary GC×GC/TOFMS Analyses, Food Analytical Methods 12 (2019) 108-120.

[10] A. Villiere, R. Symoneaux, A. Roche, A. Eslami, N. Perrot, Y. Fur, C. Prost, P. Courcoux, E. Vigneau, T. ThomasDanguin, L. Guerin, Comprehensive sensory and chemical data on the flavor of 16 red wines from two varieties: Sensory descriptive analysis, HS-SPME-GCMS volatile compounds quantitative analysis, and odoractive compounds identification by HS-SPME-GC-MS-O, Data in brief 24 (2019) 2 - 8.

[11] L. Ribeiro, F. Cosme, F. M. Nunes, Data on changes in red wine phenolic compounds and headspace aroma compounds after treatment of red wines with chitosans with different structures, Data in Brief 17 (2018) 1201 1217.

[12] L. Cai, S. Rice, J. Koziel, M. Dharmadhikari, Development of an Automated Method for Selected Aromas of Red Wines from Cold-Hardy Grapes Using Solid-Phase Microextraction and Gas Chromatography-Mass Spectrometry Olfactometry, Seaparations 4(3) (2017) 2 18.
[13] J. Kleinova, B. Klejdus, Determination of Volatiles in Beer using Solid-Phase Microextraction in Combination with Gas Chromatography/Mass Spectrometry, Czech Journal of Food Sciences, 32 (2014) 241 - 248.

[14] L. Butkhup, M. Jeenphakdee, S. Jorjong, S. Samappito, W. Samappito, S. Chowtivannakul, HS-SPME-GC-MS Analysis of Volatile Aromatic Compounds in Alcohol Related Beverages Made with Mulberry Fruits, Food Science and Biotechnology 20(4) (2011) 1021 - 1032.

[15] Y.P. Zhao, L. Wang, J.M. Li, G.R. Pei, Q.S. Liu, Comparison of Volatile Compounds in Two Brandies Using HS-SPME Coupled with GC-O, GC-MS and Sensory Evaluation, South African Journal for Enology and Viticulture 32(1) (2011) 9 - 20.

[16] P. Wiśniewska, M. Śliwińska, T. Dymerski, W. Wardencki, J. Namieśnik, The analysis of raw spirits - a review of methodology, Journal of the Institute of Brewing \& Distilling 122 (2016) 5 - 10.

[17] M. Caldeira, F. Rodrigues, R. Perestrelo, J.C. Marques, J.S. Camara, Comparison of two extraction methods for evaluation of volatile constituents patterns in commercial whiskeys Elucidation of the main odour-active compounds, Talanta 74 (2007) 78 - 90.

[18] J.S. Camara, J.C. Marquez, R.M. Perestrelo, F. Rodrigues, L. Oliveira, P. Andrade, M. Caldeira, Comparative study of the whisky aroma profile based on headspace solid phase microextraction using different fibre coatings, Journal of Chromatography A, 1150 (2007) 198 - 207.

[19] J.C.R. Demyttenaere, J.I. Sanchez Martinez, R. Verhe, P. Sandra, N. De Kimpe, Analysis of volatiles of malt whisky by solid-phase microextraction and stir bar sorptive extraction, Journal of Chromatography A, 985 (2003) 221 $-232$.

[20] G. Versini, M. A. Franco, S. Moser, P. Barchetta, G. Manca Characterisation of apple distillates from native varieties of Sardinia island and comparison with other Italian products, Food Chemistry, 113(4) (2009) 1176 - 1183.

[21] T.E. Rusu Coldea, C. Socaciu, F. Fetea, F. Ranga, R. Pârlog, Phenolic derivatives as authenticity markers of traditional homemade brandies from different counties of Transylvania, using UV-VIS and HPLC analysis, Bulletin UASVM Agriculture, 68(2) (2011) 518 - 528.

[22] P. Comuzzo, L. Tat, A. Tonizzo, F. Battistutta, Yeast derivatives (extracts and autolysates) in winemaking: Release of volatile compounds and effects on wine aroma volatility, Food Chemistry 99 (2006) 217 - 230.

[23] B. Jiang, Z. Xi, M. Luo, Z. Zhang, Comparison on aroma compounds in Cabernet Sauvignon and Merlot wines from four wine grape-growing regions in China, Food Research International, 51(2) (2013) 482 - 489.

[24] S. Farenzena, N. Tombesi, Volatile profile of Malbec wine from Buenos Aires province (Argentina), International Food Research Journal, 22(6) (2015) 2691 - 2696.

[25] R. Perestrelo, C. Silva, J.S. Camara, Madeira wine volatile profile. A platform to establish madeira wine aroma descriptors, Molecules, 3028(24) (2019) 1 - 17. 


\section{IDENTIFIKACIJA ISPARLJIVIH AROMATIČNIH JEDINJENJA VOĆNIH RAKIJA METODOM MIKROEKSTRAKCIJE NA ČVRSTOJ FAZI U KOMBINACIJI SA GASNOM HROMATOGRAFIJOM I MASENOM SPEKTROMETRIJOM}

Dragan Cvetković1, Petra Stojilković2 ${ }^{2}$ Jelena Zvezdanović ${ }^{1}$, Jelena Stanojević ${ }^{1}$, Ljiljana Stanojević ${ }^{1}$, Ivana Karabegović ${ }^{1}$

${ }^{1}$ Tehnološki fakutet, Univerzitet u Nišu, Bulevar Oslobođenja 124, 16000 Leskovac, Srbija

2 Student doktorskih studija na Tehnološkom fakultetu u Leskovcu, Univerzitet u Nišu

Optimizacija metode mikroekstrakcije na čvrstoj fazi (SPME) u kombinaciji sa gasnom hromatografijom i masenom spektrometrijom (HS-SPME-GC/MS), radi kvalitativne analize isparljivih aromatičnih jedinjenja voćnih rakija (Vilijamovka, Šljivovica, Lozovača, Kajsijevača), bila je cilj ovog istraživanja. SPME ekstrakcioni uslovi (temperatura, vreme i količina $\mathrm{NaCl}$ ) su varirani radi efikasnije hromatografske analize gasne smeše u smislu efikasnijeg isoljavanja pojedinih komponenti i uštede energije za pripremu uzorka. Optimalni uslovi su definisani kao: $T=40^{\circ} \mathrm{C} ; m_{\mathrm{NaCl}}=2 \mathrm{~g}$; razblaženje $=10$ puta. Na osnovu dobijenih rezultata zaključeno je da sastav isparljivih jedinjenja voćnih rakija, koja inače definišu njihov miris i aromu, jeste uporediv sa isparljivim sastojcima viskija. Razvoj metode u pravcu detekcije i definisanja specifičnih jedinjenja koja mogu služiti kao "otisak prsta" u proveri autentičnosti voćnih rakija predstavlja glavni cilj opisanog istraživanja.
(ORIGINALNI NAUČNI RAD) UDK 663.551.5:543.4+543.544.3 DOI: $10.5937 /$ savteh2002019C

Ključne reči: voćne rakije; aromatična jedinjenja; HS-SPME; GC/MS 